УДК 352-043.86

DOI https://doi.org/10.32851/2708-0366/2021.6.3

Явтушенко А.В. асистент,

Державний вищий навчальний заклад «Херсонський державний аграрно-економічний університет» ORCID: https://orcid.org/0000-0002-8901-0533

Yavtushenko Albina

Kherson State Agrarian and Economic University

\title{
ФОРМУВАННЯ МОДЕЛІ РОЗВИТКУ ТЕРИТОРІАЛЬНОЇ ГРОМАДИ НА ОСНОВІ СУЧАСНИХ ПІДХОДІВ
}

\section{FORMATION OF A MODEL OF TERRITORIAL COMMUNITY DEVELOPMENT ON THE BASIS OF MODERN APPROACHES}

\begin{abstract}
У статті запропоновано моделі розвитку територіальних громад, на основі сучасних підходів, основні методичні підходи, які застосовують в проиесі аналізу людського потенціалу територіальної громади. Розглянуто та проаналізовано підходи стосовно суспільного розвитку громад. Відображено основні взаємозв'язки широко вживаних моделей, підходів в процесі формування моделі розвитку об'єднаних територіальних громад. Розкрита основна сутність дослідження: сьогоденна спроможність громад, ії внутрішній потенціал (фінансовий, людський, $i$ економічний), особливості формування та застосування на рівні громад. Розглянуто та сформовано основний блок показників, для аналізування людського потенціалу територіальних громад за такими демографічними, сочіальними, економічними, трудовими, управлінськими, культурними складниками.
\end{abstract}

Ключові слова: ресурси територіальних громад системний, синергетичний, глобалізачійний, інформаційно-інноваційний, кластерний, корпоративний, соціальний, культурно-духовний, еколого-орієнтований та інші підходи; модель розвитку територіальной громади.

В статье предложены модели развития территориальных общин, на основе современных подходов, основные методические подходы, применяемые в процессе анализа человеческого потенциала территориальной общины. Рассмотреньл и проанализированьл подходы к общественному развития общин. Отражены основные взаимосвязи чироко применяемых моделей, подходов в проиессе формирования модели развития объединенных территориальных общин. Раскрыта основная сущность исследования: сегодняшняя способность общин, ее внутренний потенциал (финансовый, человеческий, и экономический), особенности формирования и применения на уровне общин. Рассмотрень и сформирован основной блок показателей, для анализа человеческого потенцииала территориальных общчин по таким демографическим, сочиальным, экономическим, трудовьм, управленческими, культурныли составляющими .

Ключевые слова: ресурсы территориальных общзн, системный, синергетический, глобализационный, информационно-инновационный, кластерныли, корпоративный, социиальный, культурно-духовный, эколого-ориентированньій и другие подходь; модель развития территориальной общчины.

The article proposes models of development of territorial communities, based on modern approaches, the main methodological approaches used in the analysis of human potential of the territorial community. Approaches to social development of communities are considered and analyzed. The main interrelations of widely used models, approaches in the process of forming a model of development of united territorial communities are reflected. The main essence of the research is revealed: the current capacity of communities, its internal potential (financial, human, and economic), features of formation and application at the community level. The basic block of indicators is considered and formed, for the analysis of human potential of territorial 
communities on such demographic, social, economic, labor, administrative, cultural components. The main problems of the choice of approaches and their application in the activities of united territorial communities, the influence of social trends on the choice of management method are studied. The application of the latest methodologies in the activities of local government, their positive and negative consequences are considered. The main aspects in the application of integration, information, environmental and innovative approaches are highlighted. The role of data collection efficiency for further analysis of community activities is determined. The practice of application of all considered principles, on an example of concrete communities is analyzed. Attracting investors, and the role of this process in the development of a united territorial community. Dependence of balanced community development on the integrated application of the analyzed approaches. The principle of application of the synergetic approach in modern conditions. The state of development of the territory at the bifurcation point is possible. Directions for implementing an innovative approach in newly created communities. Assessment of the human potential of the territorial community, using demographic, intellectual, socio-managerial, socioeconomic, socio-infrastructural indicators. The role of liberal and progressive approaches in ensuring the economic development of the community.

Key words: resources of territorial communities, systemic, synergistic, globalization, information and innovation, cluster, corporate, social, cultural and spiritual, environmentally oriented and other approaches; a model for the development of a territorial community.

Постановка проблеми. Децентралізація влади, становлення якої за останні 5 років набуває широкомасштабності, надає органам місцевої влади все більше повноважень в керуванні громадами. Спираючись на принцип субсидіарності, даний процес має на меті перехід на новий рівень відповідальності місцевої влади, за яким вона бере повну відповідальність за процес та результати управління в новостворених, укрупнених територіальних громадах. Ця особливість зумовлює застосування ефективних інструментів управління, які є однією з основних складових сучасної парадигми управління. Однією із передумов успішного розвитку об'єднаних територіальних громад $є$ формування ефективної моделі розвитку, на основі сучасних підходів.

Аналіз останніх досліджень і публікацій. Різні аспекти проблем формування ефективної моделі розвитку об'єднаних територіальних громад, висвітлювалися в роботах таких науковців: В. Бакуменко, С. Кравченко, А. Михненко [4], А. Касперовича, В. Колтун, Н. Копилова, Н. Лапіна, Т. Семигіна, О. Безуглий, Л. Лисенко.

Формулювання цілей статті. Незважаючи на те, що кожен із науковців, вивчавших тематику управління територіальних громад, зробили суттєвий внесок в обгрунтування питань формування і підходів до розвитку територіальних громад, все ж таки питання аналізу нових наукових підходів та можливостей їх застосування при моделюванні розвитку територіальних громад є досить актуальним і мало дослідженим.

Виклад основного матеріалу: Реформа місцевого самоврядування в Україні дає потребу в забезпеченні можливостей розгляду успішності діяльності об'єднаних територій. Основна частина проблем, які з'являються в процесі життедіяльності територіальних громад здебільшого пов'язана 3 нестабільністю розвитку економічного і соціального середовища, які в першу чергу свідчать про неефективне функціонування традиційних моделей і підходів, які забезпечують безперебійне функціонування об’єднаних територіальних громад (далі - ОТГ).

При плануванні розвитку територіальних громад, насамперед необхідно брати до уваги тенденції суспільства даної території, та те, яким чином вони впливають на функціонування аналізованої ОТГ. Підходи, які висвітлюють процеси суспільного розвитку територій досліджують: В. Бакуменко С. Кравченко, А. Михненко [4, с. 88]. Основні теоретико-методологічні засади соціальних підходів у системі місцевого самоврядування, які застосовуються для розвитку ОТГ, знайшли своє відображення у наукових працях Н. Бекетова, А. Касперовича, В. Колтун, Н. Копилової.

Мета статті - дати формування основним теоретико-методичним положенням, які висвітлюють застосування, як традиційних так і новітніх підходів суспільного роз- 
витку, які проявляються в забезпеченні здатності ефективного функціонування ОТГ та процесі розробки моделей їх застосування при плануванні розвитку громади.

Досить висока різноманітність та складність суспільного розвитку, вимагає постійного пошуку все більш нових підходів до їх вирішення, основними 3 яких являються такі підходи: інтеграційний, інформаційний, екологічний інноваційний, підходи, застосування, яких в процесі управлінської діяльності підсилюється засобами системного та ситуаційного підходів, а також управління якістю [1, с. 46]. Необхідно найефективніше підлаштувати дані підходи до певного рівня територіальної громади та розглянути, які проблеми чи можливості з'являться в процесі їх практичного застосування в ОТГ.

Системний підхід вважають одним 3 найбільш вживаних підходів в діяльності територіальних громад, сутністю якого є розвиток ОТГ у взаємозв'язку внутрішнього і зовнішнього середовищ. Беручи до уваги практики застосування даного принципу, вважається, що функціонування ОТГ в даних умовах має досить позитивну тенденцію, яка призводить до позитивних змін в усіх сферах і галузях. На думку вчених В. Бакуменка і С. Кравченка, даний підхід має зв'язок з процесом цілеутворення i програмно-цільовим підходом [1, с. 48-49].

На сьогодні переважна більшість ОТГ в України застосовують системний підхід в місцевих програмах соціально-економічного розвитку. Живий досвід громад Херсонщини, щодо впровадження застосування системного підходу показує, що за даною методикою ОТГ функціонує більш ефективно та враховує всі можливі ризики та загрози. Громади не лише думають про залучення інвесторів і створення нових робочих місць, а й про врахування потенційних загроз для екології, котрі можуть прийти разом із інвестором та спрямовують свої зусилля на пошук балансу задля гармонійного розвитку громади і території. Саме такий розподіл $\epsilon$ запорукою більш гармонійного розвитку регіону. Прикладом успішного впровадження даного підходу є Полтавська область, це має своє пояснення, адже економіка Полтавської області має свою специфіку, на території зосереджена досить велика кількість успішних підприємств, різного профілю, які функціонують як на рівні великих міст, так і в сільських територіях.

У практичному застосуванні цей підхід, відображає забезпечення комплексного та збалансованого розвитку територіальних громад, який грунтується на основі їх потенціалу. Однак таке його трактування значно обмежує коло застосування даного підходу, в процесі планування місцевого розвитку. Так, прагнення успішності розвитку всіх сфер не дозволяє концентрувати ресурси на розвитку пріоритетних напрямів, реалізація яких могла б покращити загальне становище території в цілому [2, с. 153].

На відміну від системного підходу, застосування синергетичного підходу дозволяє активізувати планувальну діяльність, що є закономірним етапом розвитку територіальних. При застосуванні синергетичного підходу територіальна громада, виступає системою, яка рухається за допомогою процесів самоорганізації, при цьому контролює якість всіх управлінських процесів всередині, та обирає ефективні шляхи розвитку, при можливому прояві переломних моментів (точках біфуркаціï) (рис. 1).

На даному рисунку графічно зображена точка біфуркації, яка відображає стан невизначеності, в певній діяльності, тобто певний момент часу протягом якого вирішується подальший розвиток

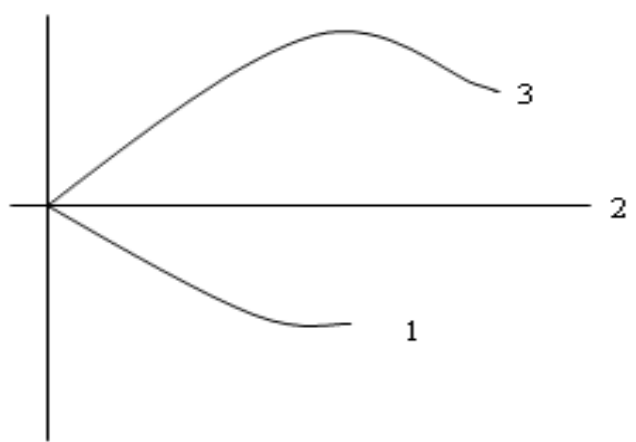

Рис. 1. Можливий стан розвитку територіальних громад в точиฺі біфуркачії 
подій. де 1 - це зменшення ефективності діяльності, 2 - ефективність не змінилась, і 3 - збільшення ефективності. У суспільстві, економіка якого переважно складається зі знань та інформації, саме ці складові стають чи не основними чинниками розвитку. Тому застосування інформаційно-інноваційного підходу набуває досить стрімких темпів. Необхідність інноваційного розвитку територіальних громад зумовлена загальною необхідністю задоволення елементарних і специфічних інноваційних потреб населення (У т. ч. на найнижчому територіальному рівні) [4, с. 116].

Інноваційність підходів до розвитку територіальних громад, має бути реалізована передусім у таких напрямах:

- використання каталізаторів і мультиплікаторів регіонального розвитку;

- мотивація регіонів до саморозвитку;

- інформування населення щодо діяльності територіальної громади;

- зростання ефективності роботи ОТГ завдяки швидкому доступу до ресурсів, знань, інноваційних технологій і постачальників, а також завдяки зменшенню трансакційних витрат [2, с. 154-155].

Якість інформаційних зв'язків впливає на корпоративний підхід управління місцевими проблемами. Застосування корпоративного підходу найбільш результативним $\epsilon$ у високоорганізованих громадах, адже в таких ОТГ в першу чергу рівно розподіляються права і обов'язки, що забезпечує рівновагу в усіх управлінських процесах, тим самим задовольняються умови для результативного впровадження даного методу. Впровадження корпоративного методу в ході розвитку ОТГ, є неминучим процесом, оскільки дає повну відповідь на зовнішні глобалізаційні виклики, такі як: партнерство між владою і населенням, міжнародними діячами і місцевими, науковими дослідженнями і впровадженнями їх в практику [10].

3 корпоративним підходом пов'язана модель організації громади, сутність якої полягає в залученні людей до співпраці, з ціллю покращення соціально-економічного становища громади, та залучення людей до організації діяльності громади для досягнення умов, за яких місцева політика і зовнішній вплив здійснюються на користь громади [2, с. $156-158]$.

Адже людський потенціал є потужною детермінантою спроможності територіальної громади. Це підтверджує його змістовність та складники оцінки (рис. 2).

\section{Спроможність громади}

Розвиток місцевого ринку праці і ринку економіки;

Дохідність місцевих бюджетів із можливістю фінансування соціальних проєктів і на розвиткові цілі

Привабливість території: інвестиційна( створення робочих місць), міграційна (протидія міграційним утратам)

Людський капітал капіталізований людський потенціал через зміну його складників та отримані натомість вигоди/втрати
Людський розвиток поліпшення середовища життєдіяльності і розвитку людини
Людський потенціалсукупні можливості населення (постійного і мобільного

Рис. 2. Людський потенціал у забезпеченні спроможності територіальної громади 
Оцінювання людського потенціалу ОТГ можна здійснити за допомогою демографічних, інтелектуальних, соціально-управлінських, соціально-економічних, соціально-інфраструктурних показників. Однією з новітніх методик оцінювання рівня людського потенціалу є їі оцінка з використанням індексного методу. Загальний методичний хід розрахунків інтегрального індексу людського потенціалу для ОТГ складається з наступних етапів:

Таблиця 1

Показники оцінки людського потенціалу територіальних громад

\begin{tabular}{|c|c|}
\hline $\begin{array}{l}\text { № } \\
\text { 3/II }\end{array}$ & ПОКАЗНИКИ \\
\hline \multicolumn{2}{|r|}{ Демографічний складник } \\
\hline 1 & $\begin{array}{l}\text { Чисельність зареєстрованого населення, різниця між зареєстрованим і фактично прожи- } \\
\text { ваючим населенням, демовідтворення за останні } 5 \text { років (втрати, приріст), чисельність } \\
\text { домогосподарств. }\end{array}$ \\
\hline \multicolumn{2}{|r|}{ Інтелектуально-трудовий складник } \\
\hline 2 & $\begin{array}{l}\text { Чисельність економічно активного населення, чисельність зайнятих, чисельність са- } \\
\text { мозайнятих, чисельність безробітних, чисельність осіб, які перебувають за кордоном } \\
\text { (мігрантів) }\end{array}$ \\
\hline \multicolumn{2}{|r|}{ Соціально-управлінський складник } \\
\hline 3 & $\begin{array}{l}\text { Чисельність співробітників в апараті ради ОТГ, середньомісячна заробітна плата праців- } \\
\text { ників, зайнятих в апараті ради ОТГ, кількість проектів міжмуніципального співробітн- } \\
\text { цтва, кількість планових зустрічей керівництва ОТГ із представниками бізнесу, раз на рік }\end{array}$ \\
\hline \multicolumn{2}{|r|}{ Соціально-економічний складник } \\
\hline 4 & $\begin{array}{l}\text { Наявний дохід у розрахунку на одного жителя, частка осіб, які потребують соціального } \\
\text { захисту, частка осіб, які отримують субсидії, чисельність суб’єктів господарювання, що } \\
\text { здійснюють діяльність в ОТГ, чисельність ФОП, що здійснюють діяльність в ОТГ, одиниць. }\end{array}$ \\
\hline \multicolumn{2}{|r|}{ Соціально-інфраструктурний складник } \\
\hline 5 & $\begin{array}{l}\text { Кількість дошкільних навчальних закладів, кількість загальноосвітніх навчальних за- } \\
\text { кладів, кількість професійно-технічних навчальних закладів, кількість закладів вищої } \\
\text { освіти, кількість закладів охорони здоров’я, кількість закладів торгівлі, наявність ЦНАП } \\
\text { на території громади, наявність відділення поліції, наявність пожежної. }\end{array}$ \\
\hline \multicolumn{2}{|r|}{ Культурний складник } \\
\hline 6 & $\begin{array}{l}\text { Кількість закладів культури, кількість мистецьких шкіл, кількість спортивних споруд, } \\
\text { кількість виставкових заходів і ярмарок на території ОТГ, кількість молодіжних центрів, } \\
\text { які функціонують на території ОТГ. }\end{array}$ \\
\hline
\end{tabular}

Першим кроком для оцінки людського потенціалу ОТГ являється розподіл і оцінка показників людського потенціалу (табл. 1) [6].

Наступним кроком оцінки людського потенціалу є розрахунок часткових та інтегральний індексів людського потенціалу, виходячи з наявних показників, отриманих із результатів соціологічних обстежень та інформаційних запитів, розраховані показники заносяться до таблиці, на основі якої будується графік динаміки часткових індексів людського потенціалу. практичне застосування даної методики обмежене наявністю відповідної інформаційної бази, отриманої із результатів соціологічних обстежень та інформаційних запитів [5, с. 324-328].

Практичне значення даної методики полягає у можливості рейтингування ОТГ за показниками людського потенціалу. Для виявлення можливостей ОТГ у більш ефективному використанні людського потенціалу з погляду забезпечення їх спроможності 
необхідно звернути увагу на розриви між частковими індексами, зокрема демографічним [9].

В основі моделі організації громади ключовим $є$ ситуативний підхід, адже сам він передбачає сполучення найвигідніших дій, враховуючи зовнішні чинники впливу, та об’єднує в собі різноманітні підходи, залежно від ситуації.

Економічний стан розвитку громади, визначається показником економічної сталості, для задоволення якої необхідне створення сприятливого середовища для ведення бізнесу, залучення інвестицій, утворення сприятливого клімату компаніям, які працюють на території ОТГ, підготовка висококваліфікованих кадрів виходячи кадрових потреб громади. Ці фактори мають безпосередній вплив на створення робочих місць, тим самим попереджатимуть відтік населення з новоствореної громади.

В забезпеченні економічного розвитку громади виділяють два основні підходи ліберальний і прогресивний. В основі ліберального підходу пріоритетним напрямком $є$ розвиток бізнесу, що в свою чергу передбачає вирішення однієї з нагальних проблем громади - безробіття, за допомогою інвестицій, які зможуть забезпечити наступне:

- створення інноваційних підприємств формування високої доданої вартості;

- випуск продукції переважно експортного спрямування;

- нові навички професійного менеджменту;

- поліпшення інфраструктури інтеграцію у світову економіку, тощо [8].

Ліберальний підхід спрямований на поліпшення місцевих умов без заперечення фундаментальних стосунків влади або нерівномірності розподілу ресурсів [5, с. 328-331].

Тоді як прогресивний підхід побудований на засадах зміцнення потенціалу громади, і передбачає поєднання соціальних та економічних цілей, орієнтацію пріоритетів у напрямі альтернативних нетрадиційних економічних форм (кооперативів, громадських бізнесових підприємств та некомерційних організацій), заохочення місцевого контролю й власності стосовно ресурсів та створення організацій для досягнення зазначених цілей, які одночасно представляли б місцеву громаду і підпорядковувалися б їй [7, с. 140-147].

Одним 3 найбільш популярних сьогодні підходів, є кластерний підхід, він надає можливості ОТГ для створення кращих умови для розвитку економіки, забезпечуючи підприємствам кращі умови доступу до більшої кількості постачальників певної продукції і послуг, висококваліфікованої робочої сили, інтенсивному обміну інформацією та передачі знань. Кластерний підхід надає економічним суб'єктам можливість зосереджуватись на можливостях розвитку, оскільки діючи як система, вони можуть використовувати ресурси більш ефективно і отримувати кращі результати

Висновки. На сьогоднішній нинішня наука пропонує широкий спектр підходів, для аналізу розвитку суспільства. Для формування моделі розвитку об’єднаної територіальної громади. Вони мають не лише науковий але й практичний характер застосування, адже вони в повній мірі враховують тенденції розвитку суспільства, та чітко відтворюють найпроблемніші сегменти.

Соціально-економічні, культурно-просвітницькі цілі розвитку ОТГ є початком для визначення підходів, які необхідно застосувати для їх в подальшого розвитку. Стратегічним планом, абсолютно кожної територіальної громади має стати самоорганізація, це актуалізує роль застосування синергетичного підходу в процесі розвитку території, адже впровадження даного підходу напряму залежить від демократизації управління місцевим розвитком, а також інтересів суб'єктів, які визначають поведінку територіальних громад у вирішенні питань місцевого значення. Розуміючи таку поведінку як складний комплекс поєднання соціальних, економічних, ментально-психологічних та інших чинників, слід враховувати, що загальний результат функціонування територіальної громади залежить від налагодження партнерства у громаді. 
Альтернативною для забезпечення розвитку територіальної громади є більш складна, порівняно із традиційними підходами, модель, яка побудована на застосуванні усіх існуючих підходів і моделей розвитку при одночасному визначенні найбільш актуальних для територіальної громади.

Зазначене знаходить своє відображення у запропонованій авторській комплексній моделі розвитку територіальної громади в сучасних умовах, яка може бути застосована для виявлення закономірностей і подальших напрямів розвитку кожної територіальної громади, визначення внутрішнього економічного і соціального стану громади та іiї поведінки у зовнішньому середовищі як прояву цього стану.

\section{Список використаних джерел:}

1. Бакуменко В.В. Аналіз проблемного поля державного управління. Проблеми й тендениії розвитку галузі науки «Державне управління» в Україні: від теорії до практики. Зб. матеріалів симп. за міжнародною участю. 2007. С. 46-49.

2. Безуглий О.В. Світовий досвід організації сталого розвитку територіальної громади. Теорія та практика державного управління : зб. наук. пр. Харків : Видавництво ХарРІ НАДУ «Магістр», 2006. Вип. 3 (15). С. 153-158.

3. Гальчинська О.А., Герасимова О.Ю., Клаф Т., Комарова Н.М. Мобілізація громади на підтримку дітей та сімей. Тренінговий модуль 3 підготовки тренерів. Фенікс, 2010. 80 с.

4. Михненко А.М., Бакуменко В.Д., Кравченко С.О. Інновації в управлінні суспільним розвитком. Навчальний посібник. НАДУ, 2009. 116 с.

5. Жовнірчик Я.Ф. Формування самодостатніх територіальних громад і стратегія їх економічного саморозвитку. Університетські наукові записки. 2005. № 1-2. С. 324-331.

6. Колтун В.С. Управління інтелектуальною складовою соціального потенціалу у місцевому самоврядуванні. Галузь науки «Державне управління»: історія, теорія, впровадження : матеріали наук.-практ. конф. за міжнар. участю, Київ, 28 травня 2010 р.

7. Копилова Н.А. Основні стратегії соціального розвитку. Теорія та практика державного управління. 2010. № 1. С. 140-147.

8. Вольська О., Ковпанець Є. Удосконалення фінансової децентралізації місцевого самоврядування. Таврійський науковий вісник. Серія: Економіка. 2020. № 4. С. 31-36. DOI: https://doi.org/10.32851/2708-0366/2020.4.4 .

9. Потравка Л., Пічура І. Публічне управління розвитком туристичної галузі в умовах трансформацій національної економіки України. Таврійський науковий вісник. Серія: Економіка. 2020. № 3. C. 30-36. DOI: https://doi.org/10.32851/2708-0366/2020.3.4.

10. Губа М.I., Карташова О.Г. Розвиток сільських територій через публічно-приватне партнерство. Державне управління: удосконалення та розвиток. 2019. № 4. URL: http://www.dy.nayka.com.ua/?op=1\&z=1414. DOI: 10.32702/2307-2156-2019.4.21

\section{References:}

1. Bakumenko V.V. (2007). Analiz problemnoho polia derzhavnoho upravlinnia. Problemy y tendentsii rozvytku haluzi nauky «Derzhavne upravlinnia» $v$ Ukraini: vid teorii do praktyky : zb. materialiv symp. za mizhnarodnoiu Uchastiu. S. 46-49.

2. Bezuhlyi O.V. (2006) Svitovyi dosvid orhanizatsii staloho rozvytku terytorialnoi hromady. Teoriia ta praktyka derzhavnoho upravlinnia : zb. nauk. pr. Kharkiv: Vyd-vo KharRI NADU "Mahistr". Vyp. 3 (15), pp. 153-158.

3. Halchynska O.A., Herasymova O.Yu., Klaf T., Komarova N.M. (2010) Mobilizatsiia hromady na pidtrymku ditei ta simei. Treninhovyi modul z pidhotovky treneriv]. Feniks, $80 \mathrm{p}$.

4. Mykhnenko A.M., Bakumenko V.D., Kravchenko S.O. (2009). Innovatsii v upravlinni suspilnym rozvytkom: navchalnyi posibnyk. NADU, $116 \mathrm{p}$.

5. Zhovnirchyk Ya.F. (2005). Formuvannia samodostatnikh terytorialnykh hromad i stratehiia yikh ekonomichnoho samorozvytku. Universytetski naukovi zapysky, no. 1-2, pp. 324-331.

6. Koltun V.S. (2010). Upravlinnia intelektualnoiu skladovoiu sotsialnoho potentsialu u mistsevomu samovriaduvanni. «Derzhavne upravlinnia»: istoriia, teoriia, vprovadzhennia : materialy nauk.prakt. konf. za mizhnar. uchastiu, Kyiv (28 travnia). 
7. Kopylova N.A. (2010). Osnovni stratehii sotsialnoho rozvytku. Teoriia ta praktyka derzhavnoho upravlinnia, no. 1, pp. 140-147.

8. Volska, O., Kovpanets, Ye. (2020). Udoskonalennia finansovoi detsentralizatsii mistsevoho samovriaduvannia. Tavriiskyi naukovyi visnyk. Seriia: Ekonomika, no. 4, pp.. 31-36. DOI: https://doi.org/10.32851/2708-0366/2020.4.4.

9. Potravka L., Pichura I. (2020). Publichne upravlinnia rozvytkom turystychnoi haluzi v umovakh transformatsii natsionalnoi ekonomiky Ukrainy. Tavriiskyi naukovyi visnyk. Seriia: Ekonomika, no. 3, pp. 30-36. DOI: https://doi.org/10.32851/2708-0366/2020.3.4.

10. Huba M.I., Kartashova O.G. (2019). Rozvitok sil's'kih teritorij cherez publichno - privatne partnerstvo [Development of rural areas through public-private partnership]. Derzhavne upravlinnya: udoskonalennya ta rozvitok, no. 4. Available at: http:/www.dy.nayka.com.ua/?op=1\&z=1414. DOI: $10.32702 / 2307-2156-2019.4 .21$. 